\title{
PROBLEMS IN USING LANGUAGE LABORATORY IN ENGLISH LISTENING INSTRUCTION
}

\author{
Feby Akhdiyati \\ Pendidikan Bahasa Pascasarjana Universitas Negeri Jakarta, Indonesia \\ E-mail: febyakhdi@yahoo.com
}

APA Citation: Akhdiyati, F. (2018). Problems in using language laboratory in English listening instruction. Indonesian EFL Journal, 4(2), 56-62. doi: 10.25134/ieflj.v4i2.1376.

Received: 11-03-2018

Accepted: 27-05-2018

Published: 01-07-2018

\begin{abstract}
This study is aimed at describing problems faced by both teachers and students in learning listening using language laboratory in SMA Sandikta, Bekasi and providing solutions to overcome those problems. The participants of the study are the eleventh-grade students of SMA Sandikta. The results of the analysis showed that there are some problems faced by the teacher and the students. The problems faced by the teacher include (1) the problems related to the teacher's proficiency like being unable to identify the error of machine, (2) insufficient collection of master tapes which makes problem for the teacher to accommodate the material, (3) too long material make the students bored, the teacher has difficulties to select of material, and (4) the attitude of the teacher and students toward language lab. On the other hand, the problems faced by the students are (1) students' lack of vocabulary, (2) physical aspects of students like boredom, and (3) the teacher did not give the tapescript, the students just memorize the dialog. For that reason, it was suggested to all parties to improve the knowledge in optimalizing the language laboratory.
\end{abstract}

Keyword: ability; language laboratory; listening; action research.

\section{INTRODUCTION}

Language is important for human being to communicate each other. Today English is the world's most widely studied foreign language. English has also played a more important role in the globalization era and culture than other international languages. Moreover, there are four language skills that should be mastered by students to accomplish the basic language skill namely: listening, speaking, reading, and writing. All of those skills should be practice and learned by students which cannot be separated to each other

Mariana C. Murcia (2000) said Listening well is an important part of learning. To understand spoken English, people need to exercise to practice listening spoken English. In fact, listening is the most frequently used language skill in everyday life.

In fact, listening is the most frequently used language skill in everyday life. As Morley (1991) said "we listen to twice as much language as we speak, four times as much as we read and five times as much as we write'.

Developing the ability to understand the foreign language takes time and continuous process. The ability to understand the foreign language should be taught and it does not happen automatically. One of the most important tasks is to provide a variety of technological aids.

According to the information above, the writer is interested in writing the research that focus on "Some Problems in Using Language Laboratory in English Listening Instruction at Eleventh Grade Students of SMA Sandikta Bekasi"

\section{Language laboratory}

English is one of the important foreign languages to be learned in Indonesia. To minimize the difficulties in teaching and learning process of English language at school, 
especially listening, it needed a facility such as language laboratory to improve students' listening skill.

Lindsay (1973) said that language lab is essentially an aid to practice. 1987) According to Oxford Advanced Learner's Dictionary of Current English language laboratory is classroom where languages are taught using tape recorder. Some theorists maintain that a language laboratory should be a purely phonetic instrument and that there is no need for any live contact between pupils and teacher. Lado (1960) states that the language laboratory is a special room for practice with sound equipment.

In other definition, Hayes (1963) language laboratory is a classroom or other area containing electronic and mechanical equipment designed and arranged to make foreign language instruction more effective.

According to E.M Stack (1966) the language laboratory is a special room designed and used primarily for foreign language learning with the aid of electronic equipment. The laboratory includes facilities to allow the teacher to listen to each individual student without being detected, to make announcements to all students or to select groups of students, and to carry on, a private conversation with any individual.

The language-teaching laboratory usually contains playback and recording equipment for students to practice the language they are studying. Language laboratory normally consist of a room or suite room containing a number of booths in which each of them is provided with a tape recorder and a head-set attached to it. And generally in front of the room there is a control desk which is operated by the teacher or instructor.

According to Lado (1964) The components of a language laboratory usually include earphones, microphones, preamplifiers, tape recorders, booths, central console, monitoring system, control switches, tape duplication facilities, recording studio, tape library and supply, and sound conditioning.

The laboratory is furnished with booths for the students. Each booth is a specially constructed table with high sides and front, shielding the occupant from the sight and sound of other students. The students sit behinds the booths and put on their head-sets. Then they usually listen to a tape recorder or teacher voice played by the teacher from the master panel desk.

The equipment in each booth is then a set of headphones, a microphone, and a tape recorder, preferably a dual-channel one, with one recording head for the student band and two playback heads, one for the program band and the other for the student band. The student can control volume through the tape recorder.

Lado (1964) states there are four main models of language laboratory systems: Audio Passive (AP), Audio Active (AA), Audio Active Comparative (AAC), and Audio Active Distributive (AAD).

\section{a. Audio Passive (AP)}

The teacher has at his one or more tape recorders and switchboard, the students each have a 'headphone', but not a microphone. The teacher can broadcast lessons to all students or to groups of students. The students practice in essentially the same way as they do in the classroom, but there is a difference: because of the headphone they cannot hear their classmates, and they can only hear a distorted version of their own speech utterances. Learner activity is restricted to listening in isolation during the presentation phrase, and to non-interactive production or reproduction during the explanation phase.

b. Audio Active (AA)

In this model of language laboratory students have headphones with microphone, which means that they can hear their own voices undistorted. This also makes it possible for the teacher to play back the voices of each individual student. This model of language laboratory supplements the possibilities for the recording of the utterances of individual students with some facilities for selfcorrection on the part of the students, correction of the utterances produced by individual students by the teacher.

c. Audio Active Comparative (AAC)

In the Audio Active Comparative Systems, the students can do all activities as those of audio system and Audio Active System. The system provides tape recorders and head-sets 
(headphone and microphone) in each student's booth.

d. Audio Active Distributive (AAD)

There is one tape recorder available for a small group of students but which in other respect has all the characteristics of the AAC laboratory, there are such laboratories as the open access and dial-access laboratories.

Some common problems displayed by students and teacher in the language laboratory are:

a. Working straight through a whole unit without stopping, then going right through again listening, thus leaving too big a time gap for effective identification and correction of errors.

b. Finishing the work before the language laboratory tine is up.

c. Being unable to do the language laboratory exercise.

d. Being unable to identify their mistakes on tape.

e. A commonly held error maintains that audio equipment for speech requires much less fidelity than for music.

\section{Listening Skill}

Listening, as one of the language skills, is of great importance in communication as there will be no communication unless what is being said is comprehend by another person. As Hornby (2000) defines listen or listened or listening as "... to pay attention to somebody something that can you hear.... To take notice of what somebody says so that you can follow their advice or believe them.. "

Listening is assuming greater and greater importance in foreign language classroom. As Rost (1994) points out, listening is vital in the language classroom because it provides input for the learner. Without understanding input at the right level, any simply cannot begin. Listening is thus fundamental to speaking.

Stack states the steps in teaching language are: listening, speaking, reading, and writing. The first two are audio-lingual skills; the last two are graphic skills.Listening is first because the students must be able to recognize the sounds of language, and differentiate among its various components.
Michael D. Bush and Robert M. Terry explained concerning with the general concept of listening:

The status of listening began to chance from one of neglect to one of increasing importance, as instructional programs of the 1970s expanded their pragmatic skill-focus on reading, writing, and speaking, including listening.

To improve their listening skill in listening English language, it is important for students to increase their language input by practicing extensive and intensive listening. Wright (1976) states that "extensive listening is the students' attempts to understand the gist of what he hears."

Jeremy Harmer explained in detail about extensive listening as follows:

Students can improve their listening skill and gain valuable language input - through a combination of extensive and intensive listening materials and procedure. Listening of both kinds is especially important since it provides the perfect opportunity to hear voices than the teacher's, enables the students to acquire good speaking habits as a result of the spoken English absorb, and helps to improve their own pronunciation and listening skill.

Extensive listening (where a teacher encourages students to choose for them what they listen to and to do so for pleasure and general language improvement) can also have a dramatic effect on a student's language learning.

Extensive listening will usually take place outside the classroom, in the student's home, car, or on personal stereos as they travel from one place to another. The motivational power of such an activity increases dramatically when students make their own choices about what they are going to listen to.

In order to encourage extensive listening teacher also needs to present the material in the classroom or language laboratory and its known as intensive listening.

Michael Rost also said that: "The prototypical intensive listening activity is dictation, the transcription of the exact words that the speaker utters. Dictation is often claimed to be an excellent integrative test (e.g. 
Cohen, 1994; Buck, 1992) because it involves listening, vocabulary, grammar, and the ability to make inferences from the context". Intensive listening is the students' attempts to understand a high proportion of what he hears or a high proportion of a certain part of the text.

Furthermore, there are at least three more intensive listening activities such as:

a. Intensive listening: using taped material

Intensive listening by using taped material or material on disk allows students to hear a variety of different voices apart from just their own teacher's. It gives them an opportunity to meet a range of different characters, especially where real people are talking. But even when tapes contain written dialogues or extracts from plays, they offer a wide variety of situation and voices.

\section{b. Intensive Listening: 'live' listening}

A popular way of ensuring genuine communication is live listening where teachers and or visitors to the class talk to the students. This has obvious advantages since students can interrupt speakers and ask for clarification. Above they can see who they are listening to 'live' listening can take the following forms:

1. Reading aloud: this allow them to hear a clear spoken version of written text.

2. Story-telling: teachers are ideally place to tell stories which, in turn provide excellent listening material.

3. Interviews: one of the most motivating listening activities is the live interview, especially where students themselves dream of the questions. In such situation, students really listen for answers they themselves have asked for, rather than adopting other people's questions.

4. Conversation: if we can persuade a native speaker or someone who competent to come to our class we can hold conversation with him or her about English or any subject. Students then have chance to watch interaction as well as listen to it.

c. Intensive Listening: the role of the teacher All activities for listening we need to be active in creating student engagement through the way we set up the task. We need to build up students' confidence by helping them listen better than by testing their listening abilities.
In particular, we need the focus on the following roles:

1. Organizer: tell students exactly what their listening purpose is, and give them clear instruction how to achieve it.

2. Machine Operator: when we use tape or disk material we need to be as efficient as possible in the way we use the tape recorder.

In listening activity, some students have problems in finding the message or the information. Many students who have difficulties in listening mostly resist their problems in some aspects.

Harmer (1991) said listening can cause problems as panic and difficulty. Students often panic when they see the tape recorder when they see the tape recorder because they know that they are faced with a challenging task. Two things are guaranteed to increase that panic, the first is to refuse to play a tape more than once and the second is to expose an individual student's lack of success in the listening task. Some teachers and students find that listening to tapes is extremely difficult, especially when tapes are fairly long.

Buck (2001) states that second-language listener could have difficulties in listening, such as unknown vocabulary, complex syntax, or the text could be just too fast, background of knowledge, and different motives for listening.

\section{METHOD}

The design of this study is descriptive evaluative. Albert J. Miles (2010) said that a descriptive case study is one that is focused and detailed, in which propositions and questions about a phenomenon are carefully scrutinized and articulated at the outset. The phenomena described in this study are related to the some problems which faced by the teacher and the students when teaching and learning listening skill through language laboratory.

This study is also called evaluative because it tries to evaluate objectively about some problems faced by the teacher and the students in using language laboratory in teaching learning listening skill. The object of 
the study includes the English teacher as a main object and the third year students of SMA Sandikta.

This research based on random sampling system. She took one class randomly from the population of four classes. For this sample the researcher hopes get the representative data.

In completing the data, the writer used two techniques, namely interview and observation. Interview was used to get more details about some problems in using language lab, the writer did an interview to the English teacher and the students concerning the research. Besides, the writer entered the classroom while the students and teacher were teaching and learning in language laboratory. She observed the using of language lab in teaching learning listening skill directly. The observation sheet is used to observe the teaching and learning process. The observation included the activities of the teacher and the students in the language laboratory.

In analyzing the data, the writer used the comparative technique. Comparative technique is an analysis of the technique that is used by the teacher in teaching listening through language laboratory and the theory of teaching listening to the experts.

\section{RESULTS AND DISCUSSION}

At least there are two important elements as source of the data in this research. First comes from the teacher and the second come from the students.

\section{Teacher's problems}

As results of the analysis, there are several problems faced by the teacher in using language laboratory. First, the teacher's preparation related to checking the condition of machinery before he used the language lab. The teacher had to assure good sound quality. This is crucial. If the sound quality is poor, the students will have difficulty in listening and understanding. The teacher in some cases being unable to identify the mistake of using language lab. The fact is that Language labs require better prepared teachers who can put the new equipment and techniques to good use as well as conduct a class.
Second, during listening activities the students often ask the teacher to slow down or to stop and replayed the video over and over again. The teacher did what his students asked; it is not helping them to learn to cope with real life situation. The students should be exposed and familiar to as much spontaneous informal talk as they can comprehend successfully. If the texts are to be played only once, repeating or re-phrasing important point, and it should generally aid comprehension. However, too much redundancy can become very unnatural.

Third, insufficient collection of master tapes and material in the language lab. It makes problem for the teacher to accommodate the materials. The collection of master tapes needs to have a special accessible only to the teachers and the lab technician and not to the students. Blank tapes of copies of the master tapes used by the students should be stored in a contiguous space with a window to the general lab space so that students may receive tapes there. The school does not have enough money to buy expensive sets of materials. However, for the standard lab which used for junior school students the school has good equipments.

Fourth, the teacher made the conversation too long. Too long conversation made students bored. The materials for the language lab should be partial materials rather than complete lesson. Labs materials have to prepared with as much if not more care than any other materials for teaching; they must be clear, graded, purposeful, and based on linguistic facts and physiological laws of learning.

Last, the class is too large for listening class. There are 39 students in a class makes students difficult to pay attention.

\section{Students' problems}

On the other hand, the problems faced by the students in using language laboratory are; 1) Students need to hear more than twice. During listening class, students often request the teacher to slow down or stop the video over and over. It does not help them actually if they in real communication. It is always a good idea to play a tape all the way through on a 
first listening so that the students can get an idea of what it sounds like; 2) the teacher did not give the tapescript when he took the material from the lab's collection. Students just memorized the dialogue; it always makes the students difficult to follow the lesson; 3) students' lack of vocabulary. They think they have to understand every word. This is very common problem faced by the students. When they are listening, they believe that they have to understand every word, if they are missing something, they feel failed and stressed. The individual's lack of success can be extremely demotivating; and 4) physical aspect of students. The information and exercises was overloaded, and the time took more than one hour, students feels bore and tired. That can make more difficult to concentrate. When they feel difficult to concentrate they begin to talk each others.

\section{ACKNOWLEDGEMENT}

In this occasion, the writer would like to express her greatest gratitude to Prof. Dr. Zainal Rafli, M.Pd. and Dr. Aceng Rahmat, M.Pd. as the writer's advisor, who has patiently given valuable help, guidance and corrections to finish this manuscript. M. Nor Abdullah, S.Pd., M.Si the Headmaster and the English teachers of SMA Sandikta, who was sincere to spend his spare time and gave much help in doing her research.

\section{CONCLUSION}

Teaching listening through language laboratory is not only one of teaching aids used to improve the students' listening ability. In many ways, language laboratory gives the students and the teacher some advantages in teaching listening skill. By using language laboratory, the students not only study about listening but they can say something with correct pronunciation, produce language without disturb other students, and study about how native speaker speaks. A language laboratory is especially useful for speaking and listening practice in that students have access to an environment that fully exposes them to native English pronunciation. In order to create this environment, the language laboratory is specially constructed to assist students in the acquisition of English by the use of English language TV and radio programmes, podcasts, WWW programmes, and other non-online video sources.

However, there are some problems faced by the teacher and the students in using language lab in teaching learning listening skill. Among those important problems, the writer may identify some of them as follows: (1) The problems faced by teacher are managing time, the students' motivation, and the students' ability, (2) The problems related to teacher's preparation before he used language lab. In some cases, he was being unable to identify the error of machine. He did not check the language lab before he used it. The problems related to the teacher's proficiency like being unable to identify the error of machine.(3) Insufficient collection of master tapes, it makes problem for the teacher to accommodate the material.(4) Too long material make the students bored, the teacher has difficulties to select of material. (5) The attitude of the teacher and students toward language lab. (6) Students' lack of vocabulary. (7) Physical aspects of students like boredom.

The writer has some suggestions related to the study. The suggestions are as follows: (1) The English teachers have to be trained how to handle and manage their laboratory to meet it effectiveness. And also given the language laboratory handbook that available for easy reference. It gives teachers sufficient confidence in operating the controls when they are actually confronted with the laboratory class. (2) Before listening task, teacher should give clear instruction and explanation about should students do and don'ts. (3) Teacher should give an interesting material, not too long and suitable with the students' need.(4) The English teacher should have to be trained and make preparation including the material and check the instruments before using the language laboratory. Because the application and the effectiveness of using language laboratory depends on both the quality of instrument and in which it is used. (5) The continuity in using language laboratory in teaching English can make the students to improve their English knowledge and skill. 
Not only for listening activities but also others aspects of English. (6) The teacher should manage the time effectively, choosing the way to make the students who have different ability in learning listening fell enjoyable, and giving motivation to the students. (7) The students are given more practicing answering in English, increasing vocabulary, note taking, improving self-confidence, and practicing listening skill. (8) For the future researcher who wants to conduct research with the some subject or different discussion, the writer hopes that this research may be useful as an addition reference.

\section{REFERENCES}

Buck, G. (2001). Assessing listening. Cambridge: Cambridge University Press.

Celce-Murcia, M. (2000) Discourse and context in language teaching. Cambridge: Cambridge University Press.

Celce-Murcia, M. (1991). Teaching English as second or foreign language ( $2^{\text {nd }} e d$.). New York: Heinle and Heinle Publisher.
Freankel, J. R., \& Wallen, N. F. (1993). How to design and evaluate research in education ( $2^{\text {nd }} e d$.). New York: Mc. Graw Hill.

Harmer, J. (2001). The practice of English language teaching $\left(3^{r d}\right.$ ed.).. Kuala Lumpur: Longman.

Hayes, S. A. (1963). What is language laboratory? Saturday Review, 70.

Oxford. (1974). Advanced learner's dictionary of current English. Oxford: Oxford University Press.

Lado, R. (1964). Language teaching: A scientific approach. New York: Mc. Graw Hill.

Lindsay, P.C.S. (1973). "Language labs: Some reflexions after ten years. ELT Journal, XXVII(1), 6.

Richards, C. J., \& Rodgers, T. S. (1986). Approaches and methods in language teaching. Cambridge: Cambridge University Press.

Stack, M. E. (1966). The language laboratory and modern language teaching. New York: Oxford University Press,

Van Ek, T., \& Van Os, C.(1977). Applied linguistics and learning and teaching of foreign language. London: Edward Arnold A Division of Hodder and Stoughton..

Wright, A. (1976).Visual materials for the language teacher. London: Longman Group. 